\title{
ECOLOGY OF THE RIFFLE INSECTS OF THE FIREHOLE RIVER, WYOMING
}

\author{
Kenneth B. Armitage \\ Department of Zoology, University of Kansas, Lawrence
}

\section{INTRODUCTION}

Most of the early work in stream biology was concerned with qualitative studies. Some studies have emphasized adaptations of stream organisms to their environment (Pearse 1939, Muttkowski 1939) ; others have considered community structure (Allee and Schmidt 1951) or stream zonation (Macan and Worthington 1951). Several biologists made faunal and zoogeographic studies (Behning 1929, Berg 1948, Thienemann 1950). Most quantitative studies were made considering the bottom fauna as fish food and have mainly been surveys to attempt to evaluate the pounds per acre of fish food available.

While working as a ranger naturalist in Yellowstone National Park, I became curious as to the effect waters from hot springs would have on the fauna of the Firehole River. My interest in quantitative ecology was stimulated because the Firehole River appeared to offer the opportunity of studying rapidly changing environmental conditions and their effect on the qualitative and quantitative composition of fauna.

This research was made possible by a National Science Foundation fellowship which enabled the author to spend several months in the field in early spring and late fall. A grant from the Gans Fund, Bethany College, W. Va., helped defray some of the expenses involved in the field operations.

The author owes a great debt to the National Park Service and to the personnel of Yellowstone National Park for their cooperation in establishing this study and for providing facilities during the late fall and early spring. Special thanks are due to Park Naturalist David de L. Condon for his efforts in making the study possible and for his continued cooperation and aid whenever needed.

Dr. Gerard A. Rohlich and Dr. Gerald W. Lawton of the College of Engineering of the University of $W$ isconsin performed a valuable service in analyzing water from the Firehole River. Dr.
Robert W. Pennak, University of Colorado, gave advice and help in making some of the identifications.

I wish to thank Dr. Arthur D. Hasler, under whose direction this work was done, for his critical evaluation of the work in progress and for the generous use of his time.

This paper is based on parts of a thesis submitted in partial fulfillment of the requirements of the Ph.D. degree at the University of Wisconsin.

\section{GEOLOGY}

The central area of Yellowstone National Park is a plateau composed of Tertiary rhyolite lava about 2000 feet thick at a mean elevation of 8000 feet (Hague 1887). Rhyolite lava is composed mainly of silica and aluminum oxide associated with other components in lesser amounts (Allen and Day 1935).

Hot spring basins lie along zones of faulting in the lava flows. The faulting has not had any appreciable effect on the general topography. However the alteration of the lava by the hydrothermal activity has made it much less resistant to erosion by streams flowing through the major geyser basins (Bauer 1948).

The Firehole River rises in Madison Lake and flows in an essentially northerly direction until its junction with the Gibbon River at Madison Junction (Figure 1). For about twelve miles it flows successively through the Upper, Midway and Lower Geyser Basins. From the Upper Geyser Basin alone the river receives sixty-eight tons of mineral matter every twenty-four hours (Bauer 1948). From this it can be inferred that the river follows a path of easy erosion and that its chemical and thermal characteristics are profoundly affected.

Some glaciation has occurred in the Firehole Valley, but no thorough study of this has been made. It is not possible at this time to evaluate 


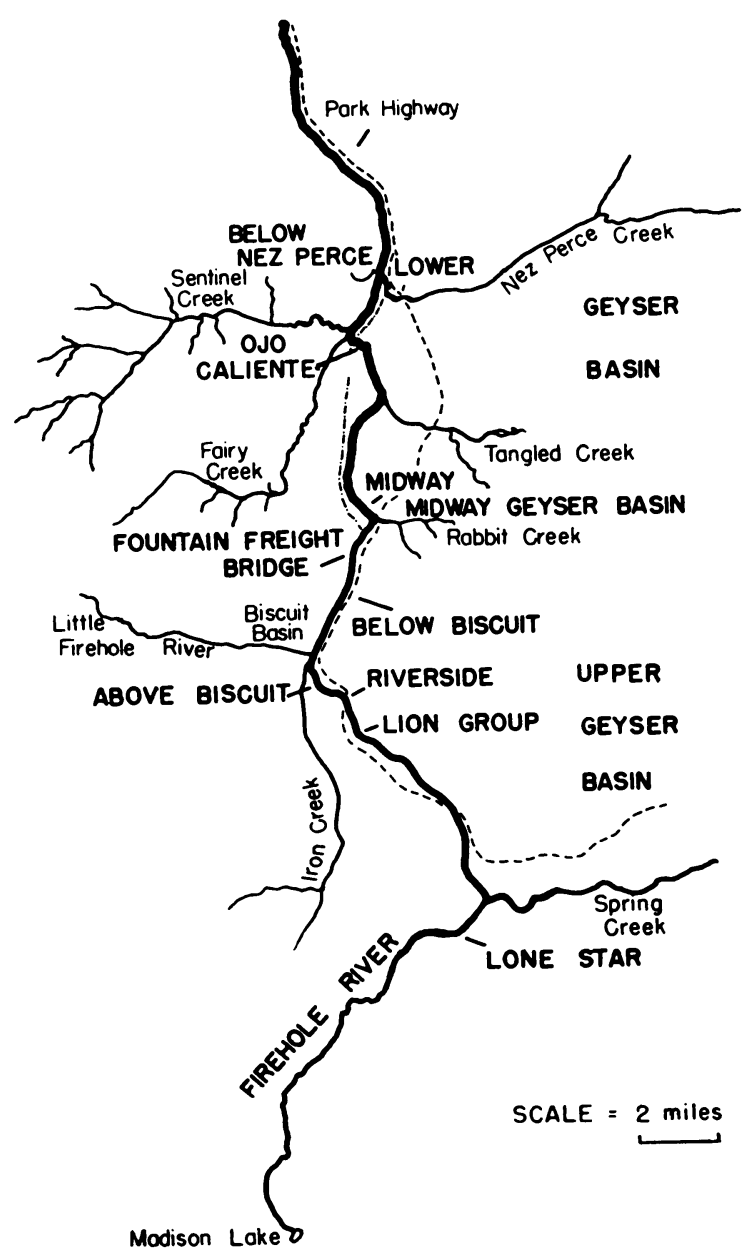

FIG. 1. Map of the Firehole River showing the locations of the sampling stations. Each station is named for a nearby geographical feature; where possible, the name is taken from a hydrothermal feature. Nez Perce, Sentinel, Fairy, Tangled, Rabbit, and Iron Creeks all receive large amounts of runoff water from hot springs. This figure was traced from the Topographic Map of Yellowstone National Park, edition of 1930. This scction extends from about $44^{\circ} 20^{\prime}$ to $44^{\circ} 40^{\prime}$ North Latitude and $111^{\circ} 00^{\prime}$ to $110^{\circ} 40^{\prime}$ West Longitude.

the contribution of glaciation to the geochemistry of the river.

\section{Description of Sampling Stations}

All sampling stations were located in riffle areas to establish as uniform a set of ecological conditions as possible. The banks of the stream at Lone Star, Below Biscuit, and Below Nez Perce stations are forested. The most abundant tree is lodgepole pine (Pinus contorta). A few scattered alpine fir (.Abics lasiocarpa) and Engelmann spruce (Picea engelmannii) are present. The banks of the remaining stations are either devoid of vegetation or covered with sedges and grasses. Plant life is absent because of the activity of the hot springs. The thermal waters deposit geyserite, a silicious sinter, which covers the soil and which apparently decomposes slowly. The locations of the stations are indicated in Figure 1 and the station types are illustrated in Figure 2.

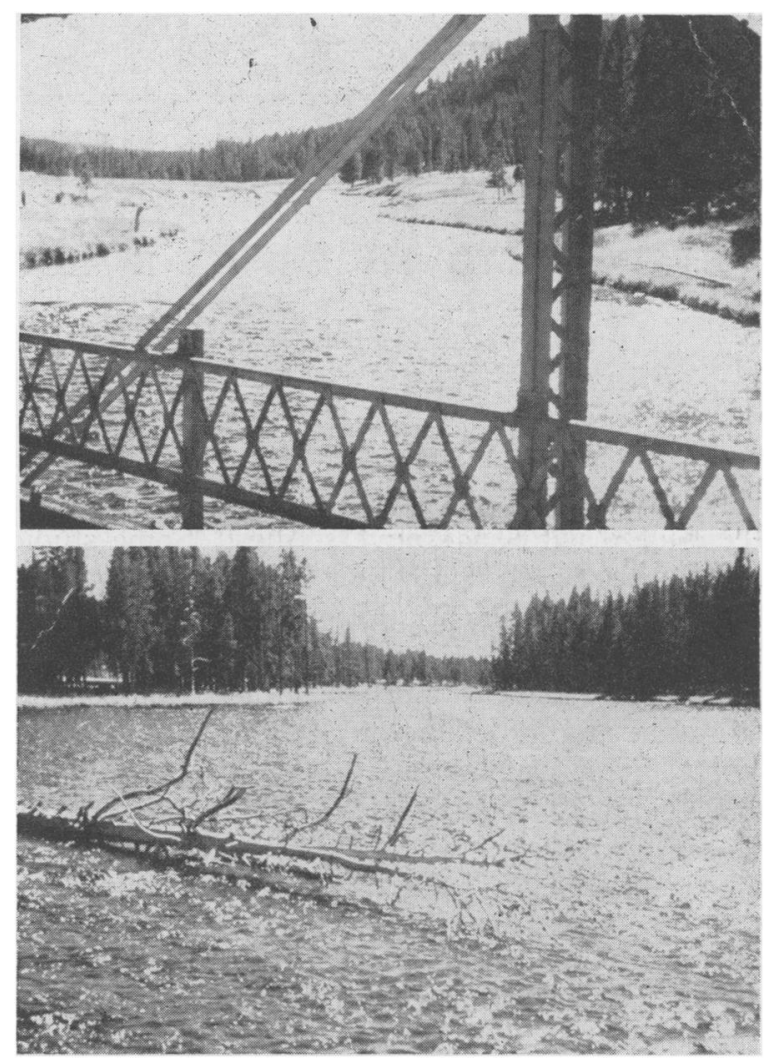

FIG. 2. (a) The Firehole River at Fountain Freight Bridge. At the left where the fisherman is standing the river bank is sedge covered. The bank in the upper third of the picture is covered with geyserite. The stream bank conditions are similar to this at Lion Group, Riverside, Above Biscuit, Midway and Ojo Caliente.

(b) The Firehole River at Below Nez Perce. Here the trees reach the water's edge. A narrow band of sedges is present along the shore. These conditions are also found at Lone Star and Below Biscuit stations.

The physical nature of the stream bottom is generally variable within each sampling station. The rubble and gravel designations follow the general use of these terms (Needham 1938). However, there does not seem to be any parallel for the bedrock formation in the Firehole River. This bedrock is lava which is very irregular, has many cracks and crevices, and often has projections or humps about the size of a piece of rubble. Thus there can be great variation in the amount of surface available for habitation in any two bedrock samples.

\section{Methods}

The nine sampling stations were established in riffle areas above and below major influxes of 
thermal water into the river. It was possible to collect from all the stations during a single day, except for a few instances in the late fall and spring when because of inclement weather two or three successive days were needed to visit all of the sampling areas. One sample was collected from each station during each trip.

In any qualitative or quantitative study of this kind, one of the basic problems is the method of collecting a sample. The Petersen dredge (Petersen 1911), the Ekman dredge (Ekman 1911), and various square-foot samplers (Needham 1928, Surber 1936, Hess 1941) are commonly used. Ide (1940) introduced a cage-trap method whereby the emerging adults are caught. Ide's method appears to give a higher value for the quantity of bottom fauna present in an area than any one of the samplers described above. But it is not always practicable to erect permanent traps in a river and one of the bottom fauna samplers still seems to be the most practical method for sampling.

All the samples from the Firehole River were collected with a modified square-foot sampler (Hess 1941). The physical nature of the substrate was determined. When there was a mixture of bottom types, they were listed in order of abundance. These data are entirely subjective, no exact quantitative means having been devised for measuring the amount of each bottom type in a sample. The collected material was emptied into a white bottom pan and sorted. The insects were preserved in 70 per cent alcohol with a few drops of formalin added.

Temperature was taken with a Taylor thermometer at the level of the sample. The Hellige Colorimetric Comparator was used to determine $\mathrm{pH}$ in the field. Alkalinity and oxygen were determined by the procedures presented in a mimeographed outline from the Department of Civil Engineering, University of Wisconsin, which are only slightly modified from "Standard Methods" (1955). Other water samples were collected, preserved by the addition of chloroform and shipped to the University of Wisconsin. The chloroform prevents the changing of insoluble products into soluble by preventing bacterial action. About three weeks elapsed from the time the samples were collected until the analyses were made.

Upon return to the University of Wisconsin the organisms were identified (Pennak 1947, 1953; Needham et al., 1935, Ross 1944, Frison 1935), counted, and weighed on Roller-Smith 100 or $1000 \mathrm{mg}$ precision balances.

To obtain more information about the various factors influencing the ecology of the bottom fauna, two other streams were surveyed.
The Gardiner River presents a situation similar to that of the Firehole River. Located in northwestern Yellowstone National Park, it drains Terrace Mountain, a travertine formation built through hot spring-activity (Bauer 1948). This mountain serves as one alkalinity source; another source is the Mammoth Hot Spring Terraces. Most of the run-off water from these springs enters the Gardiner via Hot River. Hot River, only 145 yards long, emerges from a fracture in the travertine close to the Gardiner. Its temperature is about $50^{\circ} \mathrm{C}$ and bicarbonate alkalinity averages 575 ppm (Allen and Day 1935). Samples were collected about 5 miles above the junction of the Hot and Gardiner Rivers and about 1 mile below the junction.

Lava Creek lies east of the Gardiner area. It does not drain any hot spring areas. It was chosen as a cold water stream which freezes over in winter and which might furnish evidence on the influences of alkalinity on standing crop in cold water. The samples from these rivers were collected and processed in the same manner as for the Firehold River.

\section{Results \\ Physical and Chemical Data}

Stream gradient was computed from the Topographic map of Yellowstone National Park, edition of 1930. In the Lone Star region it is about 1.4 feet per 100 feet. The river then drops about 150 feet per 100 feet at the Kepler Cascades. The gradient througout the remaining stations is about 0.63 feet per 100 feet.

The volume of flow measured below Biscuit Basin, September 2, 1929, was $135 \mathrm{ft}^{3} / \mathrm{sec}$ (Allen and Day 1935). The total discharge from hot springs amounts to $54.9 \mathrm{ft}^{3} / \mathrm{sec}$; of this only .06 $\mathrm{ft}^{3} / \mathrm{sec}$ enters the river in the Lone Star Area, $18.3 \mathrm{ft}^{3} / \mathrm{sec}$ enters from the Upper Basin, $0.22 \mathrm{ft}$ $3 / \mathrm{sec}$ between the Upper and Midway Basins, $12.94 \mathrm{ft}^{3} / \mathrm{sec}$ from Midway Basin, and $23.28 \mathrm{ft}$ $3 / \mathrm{sec}$ from the Lower Basin. From this it would be expected that major faunal changes might occur in the regions of the Upper, Midway and Lower Basins.

The role played by stream flow falls into two categories. A marked decrease of volume might expose some sessile organisms which would be killed (Taft and Shapovalov 1935). A sudden increase in volume might create a surge sufficient to carry off bottom organisms (Maciolek and Needham 1951). Neither of these extreme conditions was observed in the Firehole River. The increase of flow after the May thaws is gradual 
TABLE I. Results of chemical analyses made at the University of Wisconsin. Results are expressed as $\mathrm{mg} / 1$

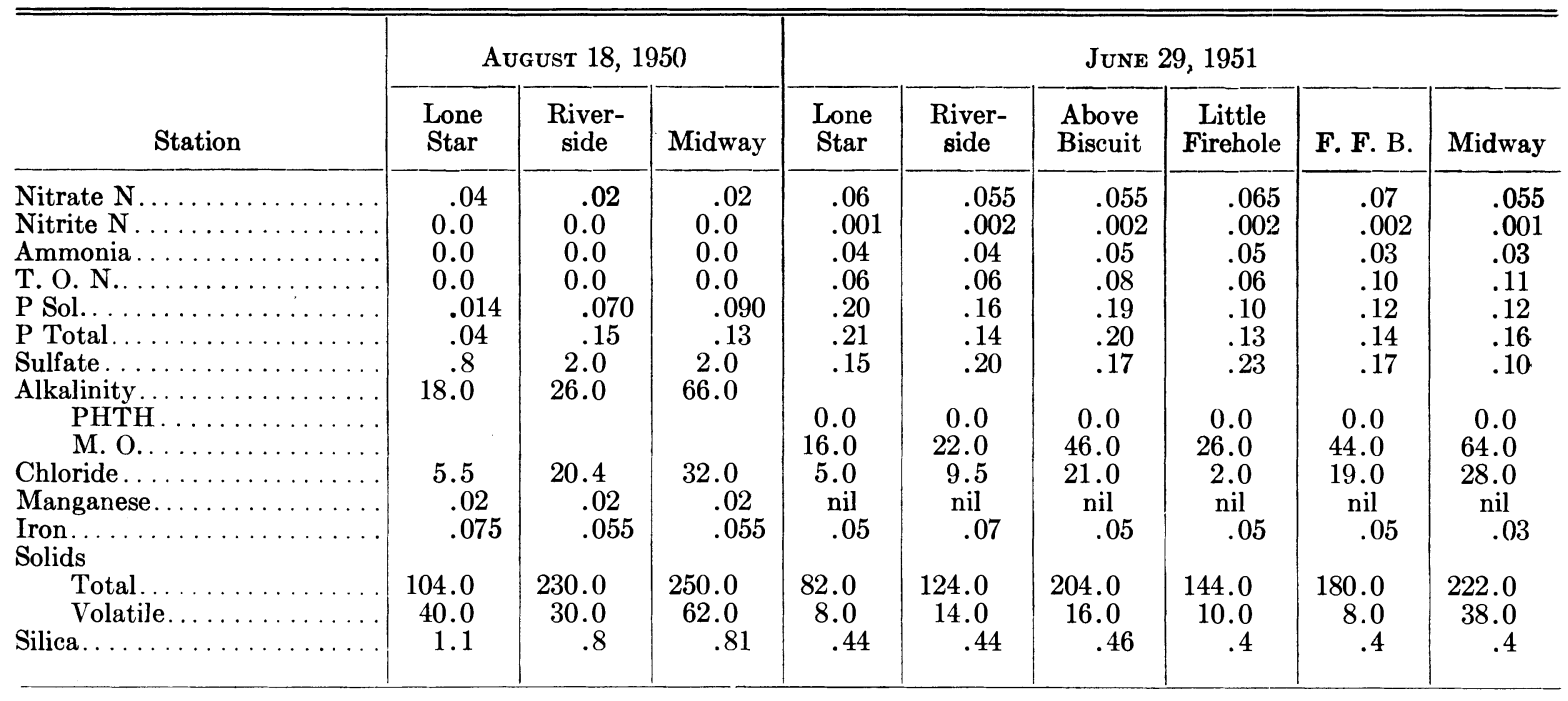

and does not appear to have major deleterious effects.

Table I shows the results of the chemical analyses made at the University of Wisconsin. The 1950 sample was collected August 18 when the water volume was low and the 1951 sample was collected June 29 when the water volume was high. At this latter date a larger amount of melted snow water contributed to the total volume than in the other sample. Although the larger volume of melted snow water might account for the generally lower values in the spring sample, it does not explain the absence of several of the nitrogen components in the fall sample. Rather it is likely the result of analytical errors. The phosphorus is particularly abundant and at such high concentrations is unlikely to be a limiting factor in the production of organisms. Three of the constituents, total solids, chloride, and alkalinity, show a progressive downstream increase. The increase is not continuous because of the diluting effect of side streams such as the Little Firehole River. Chloride at these concentrations has not been shown to have any effect on bottom fauna. Solids vary so much with the season of the year that this does not seem to be an ecological factor which lends itself to analysis or to correlation with bottom fauna distribution. However, alkalinity fluctuates less widely and may offer better opportunities for analysis.

A summary of the data collected on alkalinity, temperature, and $\mathrm{pH}$ is presented in Table II. In general, all of these show a progressive downstream increase. Alkalinity is represented entirely by methyl orange or bicarbonate alkalinity. The downstream increase can be attributed to the influx of hot spring water. Thirty-six analyses of
TABle II. Summary of physical-chemical data. These data were collected between July 13 -October 12,1952 and May 7-May 25, 1953. Average temperature and average alkalinity are numerical averages of 16 samples and 8 samples respectively

\begin{tabular}{|c|c|c|c|c|c|c|c|c|c|}
\hline Station: & 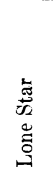 & 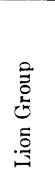 & 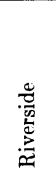 & 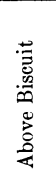 & 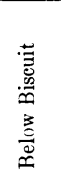 & 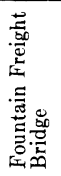 & 窟 & 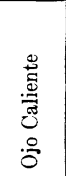 & 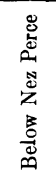 \\
\hline \multicolumn{10}{|l|}{$\begin{array}{l}\text { Temperature } \\
\mathrm{C}^{\mathrm{C}}\end{array}$} \\
\hline Range. & $6-14$ & $7-16$ & $12-18$ & $13-20$ & $15-21$ & $13-21$ & $17-23$ & 18-24 & $16-23$ \\
\hline Average. & 10.2 & 11.7 & 14.5 & 16.6 & 18.1 & 17.4 & 19.4 & 20.7 & 18.7 \\
\hline \multicolumn{10}{|l|}{$\begin{array}{c}\text { Alkalinity } \\
\mathrm{mg} / 1 \text { of } \\
\mathrm{CaCO} 3\end{array}$} \\
\hline Range. & $18-20$ & $18-26$ & $34-40$ & 50-58 & $42-54$ & $48-60$ & 54-72 & $84-100$ & 56-88 \\
\hline Average. & 19.5 & 20.3 & 37.3 & 53.5 & 45.3 & 54.8 & 65.8 & 92.5 & 76.3 \\
\hline pH & & & & & & & & & \\
\hline Range. & $\begin{array}{c}6.6- \\
7.0\end{array}$ & $\begin{array}{c}6.6- \\
7.2\end{array}$ & $\begin{array}{c}7.2- \\
8.0\end{array}$ & $\begin{array}{c}7.6- \\
8.2\end{array}$ & $\begin{array}{r}7.6- \\
8.0\end{array}$ & $\begin{array}{r}7.6- \\
8.2\end{array}$ & $\begin{array}{c}8.0- \\
8.4\end{array}$ & $\begin{array}{r}7.8- \\
8.2\end{array}$ & $\begin{array}{r}7.4- \\
8.4\end{array}$ \\
\hline
\end{tabular}

hot spring water in the Upper Basin show an average of $416 \mathrm{ppm}$ of bicarbonate, six analyses in Midway Basin, $458 \mathrm{ppm}$, and eleven analyses in the Lower Basin, 349 ppm (Allen and Day 1935).

In general, oxygen is not a limiting factor in mountain streams. Two analyses made in the summer of 1952 showed a range of $6.0-7.1 \mathrm{mg} / 1$. Most of the results showed about 100 percent saturation for that elevation.

\section{Standing Crop and Production of Bottom-fauna}

Total annual standing crop is presented in Table III and the average seasonal variation in standing crop in Table IV. Table IV also gives some information about production. The total average 
weight of bottom fauna of the Firehole River increases about $870 \mathrm{mg} / \mathrm{ft}^{2}$ from the fall low to the spring maximum. This increase in the standing crop represents the minimum bottom-fauna production by the river over that period. A more accurate way of studying the minimum bottom-fauna production of a river is to collect emerging adults throughout the year. Since each adult began life in the river as an egg, the weight of the adult represents an absolute gain in mass. Sprules (1947) found that 66-79 percent of the insects emerged before July 17 and 20-33 percent between that date and September 11. This corresponds fairly well with bottom fauna numbers which are high in the spring and early summer, and low in the late summer. A comparison of the numbers of bottom-fauna found from May through July 20 with those present from July 20-September 15 shows that 63 percent of the numbers were present in the spring and 37 percent in the summer. From this at appears that the standing crop can give a fairly accurate indication of the level of productivity of bottom-fauna for a particular time of the year. In the fall the standing crop is reduced to its base level and the difference between that base level and the standing crop at any given time indicates the minimum net production for that period. However, standing crop does not give production data, but differences in the standing crop of insects from one sampling station to another, or from one river to another indicate the differences in the productivity (capacity to produce) of insects of the two areas. Thus the values in Table IV indicate (in a general way) the relative productivities of the various sampling stations.

That the standing crop of insects can reflect the relative productivity of a fauna stems from the

TAble III. Bottom fauna standing crop for all Yellowstone Park stations. Fifteen samples were collected from each station in the Firehole River and five samples from the other streams

\begin{tabular}{|c|c|c|c|c|}
\hline Station & $\begin{array}{l}\text { Total } \\
\text { No. }\end{array}$ & $\begin{array}{c}\text { Total wt. } \\
\text { mg }\end{array}$ & $\begin{array}{c}\text { Av. No. } \\
\left(\text { no } / \mathrm{ft}^{2}\right)\end{array}$ & $\begin{array}{l}\text { Av. wt. } \\
\left(\mathrm{mg} / \mathrm{ft}^{2}\right)\end{array}$ \\
\hline 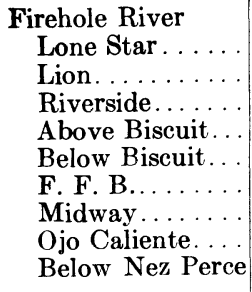 & $\begin{array}{r}409 \\
1,324 \\
1,096 \\
1,491 \\
1,366 \\
1,359 \\
2,091 \\
1,540 \\
991\end{array}$ & $\begin{array}{r}1,183.2 \\
8,712.0 \\
4,303.4 \\
10,613.8 \\
9,458.4 \\
6,864.3 \\
13,026.2 \\
8,260.0 \\
9,608.1\end{array}$ & $\begin{array}{r}27.2 \\
88.2 \\
73.0 \\
99.4 \\
91.0 \\
90.6 \\
139.4 \\
110.8 \\
66.0\end{array}$ & $\begin{array}{r}78.8 \\
580.8 \\
286.8 \\
707.5 \\
630.5 \\
457.6 \\
868.4 \\
550.6 \\
640.5\end{array}$ \\
\hline $\begin{array}{l}\text { Lava Creek...... } \\
\text { Upper Gardiner. } \\
\text { Lower Gardiner. }\end{array}$ & $\begin{array}{r}602 \\
259 \\
1,488\end{array}$ & $\begin{array}{r}3,318.5 \\
2,409.1 \\
14,637.8\end{array}$ & $\begin{array}{r}120.4 \\
51.8 \\
297.6\end{array}$ & $\begin{array}{r}663.7 \\
481.8 \\
2,927.5\end{array}$ \\
\hline
\end{tabular}

*These data can be converted to numbers or weight per square meter by multiplying the values per square foot by 10.76 .
TABle IV. Average seasonal variation in standing crop in Yellowstone Park streams and for selected stations of the Firehole River. Average number and average weight are the numerical averages of the samples collected in each season. The values for the Firehole River are averages of all stations for each season. The number of samples is indicated in parentheses after the average number

\begin{tabular}{|c|c|c|c|c|c|c|}
\hline & \multicolumn{2}{|c|}{ SUMMER } & \multicolumn{2}{|c|}{$F_{A L L}$} & \multicolumn{2}{|c|}{ SPRING } \\
\hline & Av. No. & $\begin{array}{c}\text { Av. Wt. } \\
\text { (mg) }\end{array}$ & Av. No. & $\begin{array}{c}\text { Av. Wt. } \\
(\mathrm{mg})\end{array}$ & Av. No. & $\begin{array}{c}\text { Av. Wt. } \\
\text { (mg) }\end{array}$ \\
\hline Firehole River....... & $73.0(6)$ & 480.7 & $81.5(6)$ & 300.6 & $150.7(3)$ & 1170.7 \\
\hline Riverside..... & 40.0 & 146.6 & 84.6 & 139.5 & 116.0 & 862.0 \\
\hline Below Biscuit. & 81.6 & 618.9 & 57.0 & 258.0 & 179.0 & 1398.9 \\
\hline Midway....... & 105.8 & 658.5 & 116.0 & 402.4 & 253.3 & 2222.0 \\
\hline Ojo Caliente..... & 77.1 & 418.3 & 55.5 & 214.6 & 288.6 & 1487.3 \\
\hline Upper Gardiner. . & & & $60.0(3)$ & $2 \div 5.3$ & $40.5(2)$ & 761.5 \\
\hline Lower Gardiner.. & & & $242.0(3)$ & 1735.0 & $380.5(2)$ & 4716.4 \\
\hline Lava Creek...... & & & $145.3(3)$ & 537.3 & $83.0(2)$ & 853.2 \\
\hline
\end{tabular}

nature of the insect life histories. Most of the insects of streams have an annual turnover. When such a species hatches, most of the population is removed from the stream in a period of several days or a few weeks. Thus the population is reduced to zero and grows back to its peak in the subsequent year. Ordinarily a population of stream insects is not reduced to zero as the period of emergence varies from species to species and some species have life cycles of two or three years with only a part of the population emerging in any one year. The interplay of life histories produces the annual cycle of abundance of insects as described above.

Since the termination of population growth of stream insects results in the removal of most of the adult population from the area, it seems that the population dynamics of stream insects differs from that of other consumers in the aquatic environment in that certain extreme conditions do not occur. Some examples of the conditions which can prevail with other aquatic organisms should clarify this difference. The standing crop of plankton can be low in water of high productivity if the plankters are removed by a higher trophic level as fast as they are produced. Because of the relatively short life cycles of plankters, a relatively high production can result even though the standing crop is relatively low. This situation cannot occur with stream insects because of the length of the life cycle. Such a rapid removal would deplete the population and result in the extinction of its components. Neither would one expect to find a high standing crop of stream insects associated with a low productivity as would be possible with indeterminate growers, such as fish. For, although fish can show little growth for 
several years, most of the stream insects complete growth in one year and leave the environment, thus allowing the cycle of growth to occur again.

One factor which can markedly influence the level of the standing crop is predation. A situation could theoretically exist in which one stream with a much greater productivity, could have a much lower standing crop than a second stream of lower productivity because of the activities of predators. Hayne and Ball (1956) have demonstrated that this condition can occur with respect to bottom fauna in ponds. However, their calculations indicate that the more productive pond would also have a higher standing crop, but the rate of production was much higher in the more productive pond than the difference in standing crop would indicate. This paper by Hayne and Ball indicates that at any one time a pond can support a definite biomass of bottom organisms. As some of the biomass was removed by predation and undetermined factors, it was replaced. Their data do not show how the replacement occurred. One could postulate that increased growth of the remaining organisms replaced the biomass that was removed.

In natural environments where several trophic levels exist, one would expect that the reproduction and growth of the bottom organisms would be adjusted to the various factors which regulate the population (see, for example, Lack 1954). Thus one would not expect to find the conditions established by Hayne and Ball occurring in natural environments, i.e., one environment (such as a stream) with predators and the other environment without predators. In summary, standing crop can indicate in a general way the relative productivity of insects of the bottom of streams, but the differences in standing crop are unlikely to be proportional to the differences in the rates of production.

Seasonal variation in standing-crop of bottomfauna seems well established. Needham (1934) found the greatest seasonal abundance for both numbers and weight in May and a lesser peak of abundance in November during a mild winter. A later study of the same riffle presented the same situation. Maciolek and Needham (1951) found an August low and a February high. Apparently samples were not collected later in the spring. All the streams studied in Yellowstone Park show the pattern of a fall low and spring high in total weight of organisms. The Upper Gardiner and Lava Creek both show a decrease in numbers, but an increase in weight. Both of these areas freeze in the winter and it is possible that the break-up of the ice might reduce the numbers but the re- maining organisms are large enough to produce an over-all increase in weight. The Firehole River studied as a whole does show a very definite pattern. The numbers increase from summer to fall to spring while the mass decreases from summer to fall and increases to spring. The total weight in spring is higher than the summer weight.

The physical composition of the stream-bottom also influences standing crop. Studies by Needham (1928, 1929, 1934), Behney (1937), Pate (1932, 1934), Pennak and Van Gerpen (1947), Percival and Whitehead (1929), and Sprules (1947) all indicate a higher standing crop on rubble than on gravel in both numbers and weight. In the Firehole River as a whole, rubble is also associated with high standing crop to a greater degree than is bedrock. Through all seasons 37 rubble samples averaged 112.8 organisms weighing $919.7 \mathrm{mg} / \mathrm{ft}^{2}$ and 56 bedrock samples averaged 78.2 organisms weighing $369.9 \mathrm{mg} / \mathrm{ft}^{2}$. On the average, rubble contains 1.44 times the number and 2.48 times the weight of organisms on bedrock.

There are a number of generalized statements in the literature concerning other factors affecting the standing crop of bottom-fauna. Needham (1934) states that warm streams are richer in foods than cold ones. Taft and Shapovalov (1935) state "in general, high alkalinity readings are indicative of streams rich in bottom fish foods."

In order to test these statements, the average weight values of Table III were adjusted to eliminate the effect of the composition of the bottom of the stream. This was done by multiplying the weight of each bedrock sample by a factor of 2.48 , the average weight difference between bedrock and rubble samples. The adjusted samples were then added to the untreated samples to obtain an adjusted total weight for each station and an adjusted average weight was determined from this. Correlation coefficients with adjusted average weight were as follows:

with average temperature $=.386$

with average alkalinity $=.839$ (significant at the 1 percent level).

Correlation coefficients also were determined between the untreated average weight of Table III and the following:

$$
\begin{aligned}
& \text { average temperature }=.274 \\
& \text { average alkalinity }=.74 \quad(\text { significant at the } 1 \\
&\text { percent level }) .
\end{aligned}
$$

Although there is some positive correlation with temperature, these results indicate that bicarbonate alkalinity is likely to be more important than temperature in influencing the weight of bottomfauna. This is supported by other evidence. 


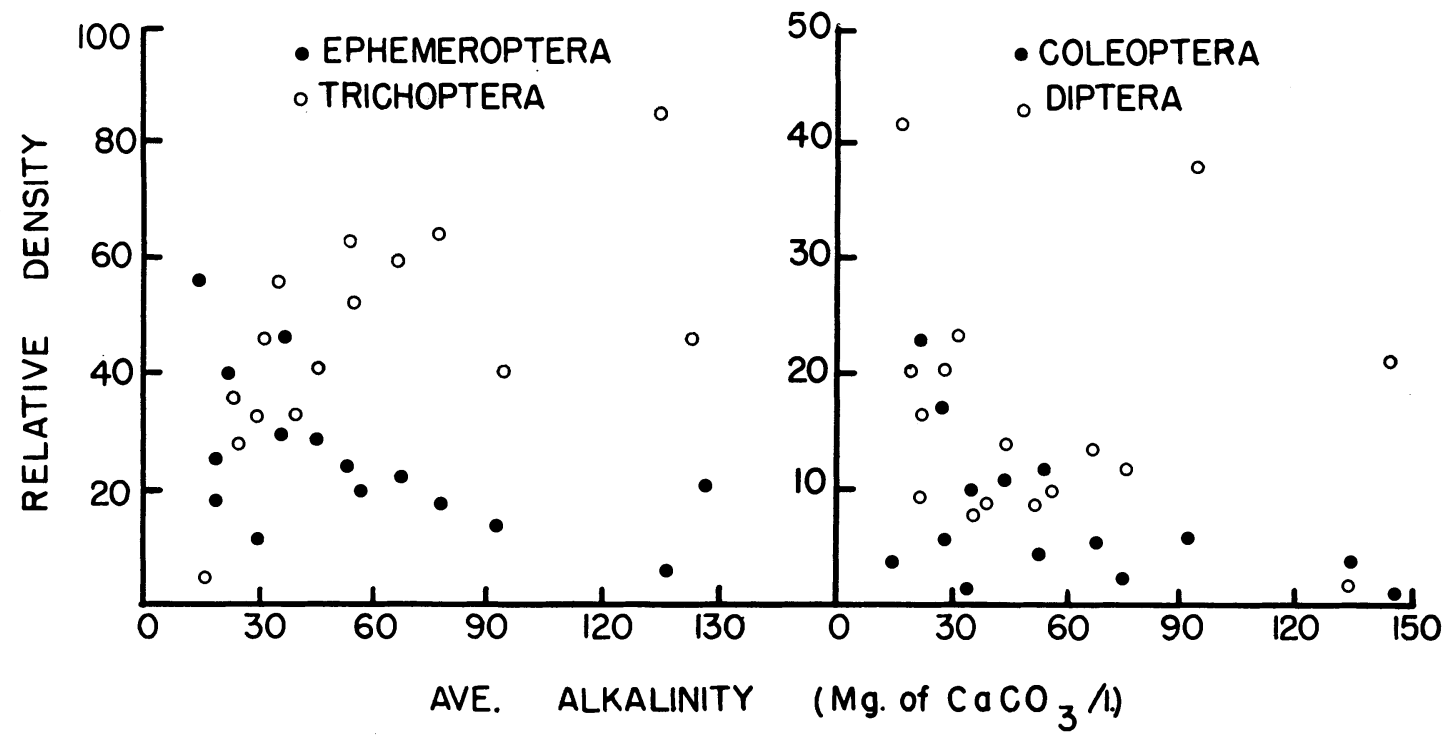

FIG. 3. Relative density of four orders of insects plotted against average alkalinity. Relative density is computed by dividing the numbers of an organism or group of organisms by the total number of organisms present times 100. Data from all Yellowstone Park streams and from Allen (1951), Pennak and Van Gerpen (1947), and Gaufin (1949).

Gaufin's (1949) studies of the North and South Forks of the Provo River, Utah, indicated a temperature difference between the two forks of $0.3^{\circ} \mathrm{C}$, but the South Fork shows an increase of $121 \mathrm{ppm}$ in alkalinity. The numbers of bottom organisms in the South Fork are nearly twice those of the North Fork and the weight seven times as much. This difference occurs in spite of the fact that the North Fork has a rubble bottom and the South Fork a gravel bottom. Pennak and Van Gerpen (1947) write that the numbers in a northern Colorado trout stream are low in comparison to other streams, "and there does not seem to be any logical ecological explanation." Although the temperature of the Colorado stream ranges to $20.6^{\circ} \mathrm{C}$, the alkalinity varies from 10 to $25 \mathrm{ppm}$, and the numbers and weight of the bottom-fauna compare favorably with the upper part of the Firehole River; the values are intermediate between those of the Lone Star and Lion Stations.

The relative abundance of the major insect orders also changes with change in average alkalinity. Figure 3 shows the results of plotting relative-density of the four orders from the Yellowstone Park streams and three other streams against average alkalinity. The correlation-coefficients of these plots were determined with the following values :

\begin{tabular}{|c|c|c|}
\hline Trichoptera & .75 & $\begin{array}{l}\text { (significant at the } 1 \\
\text { percent level) }\end{array}$ \\
\hline Ephemeroptera & -.702 & $\begin{array}{l}\text { (significant at the } 1 \\
\text { percent level) }\end{array}$ \\
\hline Diptera & -.184 & $\begin{array}{l}\text { (non-significant at the } \\
5 \text { percent level). }\end{array}$ \\
\hline
\end{tabular}

$$
\begin{gathered}
\text { Coleoptera }-.45 \quad \text { (non-significant at the } \\
5 \text { percent level). }
\end{gathered}
$$

A number of distinct aberrations from the general distribution appear in Figure 3. All of these are instances of the effect of the composition of the stream bottom upon the distribution of bottomfauna (Armitage 1954). For example, gravel bottom has been shown to have a high proportion of Diptera (Gaufin 1949, Pennak and Van Gerpen 1947, Sprules 1947). Since many of the dipterous forms are small, they are able to take advantage of the small crevices available in this bottom condition--crevices that larger forms cannot utilize.

\section{Discussion}

In any study of this sort prime consideration must be given to the adequacy of the sampling. The error in sampling is very large. Leonard (1939) found that species composition between samples from a similar area varied from 20 to 40 percent. The total fauna varied 23.2 percent for five samples and 17.5 percent for ten samples. He concluded :

"One sample of the sort described may be depended upon to yield a reasonably accurate index of the amount of food organisms produced per unit area of uniform bottom, but cannot be expected to provide a comprehensive picture of the relative numbers of individual species throughout the larger areas from which the sample is collected."

Needham and Usinger (1956) determined the variability in macrofauna in a single riffle using 
the Surber sampler. They found that 194 samples were needed to give acceptable figures for total wet weight of organisms and 73 samples were needed to give significant figures for total numbers acceptable by their standards at $95 \%$ level.

There seem to be two reasons for this error. One source of error is the variable efficiency of the sampler. A square-foot sampler on some types of stream bottom will take in either more or less than a square-foot because of the nature of the bottom. When the edge of the sampler falls on a rock, is that rock included in the sample, removed from the sample, or does the biologist attempt to collect only from that part of the rock within the limits of the sampler? When one is working in swift current and must place the sampler with some force, there can be no doubt that considerable variation results in the amount of substrate that is included in the sample. The other source of error lies in the nature of the distribution of the bottom-fauna. A riffle is a series of intergrading communities. Any one square foot sample probably selects from several communities; another sample may select from different communities, or, if sampling is from the same communities, the constituents of the communities may be present in different proportions.

It seems clear from the above considerations that any quantitative analysis of distribution of bottom-fauna must be made with caution since it is impossible for a single biologist to collect enough samples to meet very rigid requirements of significance at the $95 \%$ confidence level for numbers or weight of organisms per square foot in a sampling area. However, some relationships between bottom-fauna numbers and weight and certain ecological factors seem to be emerging from the many studies of stream biology. Alkalinity is one of these factors which merits further discussion.

Alkalinity is a measurement of the bicarbonate ion which plants can utilize in photosynthesis. Unless there is some other chemical limitant (such as phosphorus), higher alkalinity results in an increase in the plant life of the stream-bottom. This furnishes an increased food supply and an increase in available surface for attachment. But there may be an upper limit, for Percival and Whitehead (1929) have shown that on thick beds of moss the standing crop of insect decreases and is much lower than the standing crop of insects on loose moss on rocks or of insects on loose stones. But within the limits of alkalinity of most mountain streams that have been studied to date, the insect fauna which is qualitatively determined by such factors as temperature, current, and bottom-composition increases in numbers and weight with increased alkalinity.

Other studies tend to support the concept of the positive influence of bicarbonate alkalinity on standing crop. Johnson and Hasler (1954) studied production of trout and standing crop of zooplankton in three small dystrophic lakes near the Michigan-Wisconsin boundary. Two lakes were treated with lime which increased their bicarbonate alkalinity. One of these lakes was a twin to the untreated lake which served as a control. The standing-crop of No. 2 net zooplankton expressed as grams of dry weight per square meter of lake surface was 0.81 in the treated twin lake and in the untreated twin with lower alkalinity it was 0.64 . The other treated lake had a value of 0.77 $\mathrm{g} / \mathrm{m}^{2}$. Borecky (1956) found a correlation between the densities of Cladocera and hydrogen ion, carbonate ion, and bicarbonate ion in Pymatuning Reservoir. These ions were interpreted as indexes of photosynthetic activity so that their effects were manifested in the food supply of the Cladocera. Frost (1945) found that a $200 \mathrm{gm}$ wet weight moss sample from alkaline water (170 ppm alk.) had larger forms than a comparable sample from acid waters (14 ppm alk.). Both Trichoptera and Ephemeroptera were more abundant in the alkaline waters.

There have been numerous attempts to evaluate the relative importance of the various environmental factors in determining the quantity of bottom organisms. Linduska (1942) considered the bottom of prime importance. Gaufin (1949) chose the most variable factors: volume, velocity, alkalinity, and bottom composition as responsible for differences in the Provo River. Needham (1934) considered depth, bottom, and current as most important; Sprules (1947) picked temperature, nature and configuration of bottom-particles, and rate of flow to be the chief determinants. Ricker (1934) utilized speed of current, type of bottom, temperature, width and depth, flora, fauna, and chemical characteristics in making a classification of Ontario streams. As Ricker pointed out, these factors are interdependent. Any one or some combination may appear to be the main factor or factors in any one stream. In his classification Ricker used volume of flow and temperature as primary characters, current-speed and bottomtexture as secondary characters, and dissolved solids as tertiary characters. These seem to form rather natural groupings, especially if qualitative faunal differences are considered, but do not carry any implications concerning the quantity of bottom organisms.

In the Firehole River, bicarbonates appear to be 
the main factor in determining total quantity of organisms. Other factors such as bottom-type and temperateure modify the activity of the bicarbonates. Our present knowledge is insufficient to allow us to distinguish factors of prime importance and of secondary importance, although the correlation between alkalinity and standing crop of bottom fauna indicates that alkalinity, as an indicator of available food, might be the prime factor. Any classification of factors in order of importance at present should be for local pragmatic use in stream management and not for the purpose of establishing an ecological principle.

\section{SumMARY}

The Firehole River flows along a fault in a rhyolite lava plateau and through a series of centers of hydro-thermal activity. The runoff water from the hot springs flows into the river and profoundly changes its physical and chemical characteristics. This change is evident in the progressive downstream increase in temperature, $\mathrm{pH}$, and alkalinity.

Nine stations for sampling bottom fauna were located along the river above and below all the major influxes of hot spring water into the river. The samples of bottom organisms were collected from July through October 1952, and in May 1953. The organisms were identified, counted, and weighed.

The Gardiner River and Lava Creek were surveyed to gather more information about the various factors influencing the ecology of the bottom-fauna. The Gardiner River was sampled above and below an inflow of hydro-thermal water. Lava Creek does not receive any hot spring water.

The average yearly standing-crop of the Firehole River and other Yellowstone Park streams was positively correlated with temperature and bicarbonate alkalinity, the latter being highly significant. Analysis of data from other streams and lakes further illustrated the influence of alkalinity on standing crop of organisms.

Standing crop, as expressed by weight, was shown to be high in the spring with a gradual decrease in the summer to a low in the fall. Another factor influencing the level of standing crop is the physical composition of the stream bottom. Rubble bottom had an average of 2.48 times the weight of organisms on bedrock.

The relative-density of Trichoptera, Ephemeroptera, Coleoptera, and Diptera was plotted against average alkalinity. Trichoptera had a statistically significant positive correlation, Ephemeroptera had a significant negative correlation, and
Coleoptera and Diptera had a negative but nonsignificant correlation.

It was postulated that alkalinity might be the chief factor that determines the level of standing crop in a stream, but that this level can be highly modified by the action of temperature and current and by the physical composition of the stream bottom. Since all of the above mentioned factors interact to determine the level of the standing crop of bottom fauna, it does not seem possible to establish any system of stream classification based on a hierarchy of importance of the various environmental factors except for local pragmatic use in stream management.

\section{REFERENCES}

Allee, W. C. and K. P. Schmidt. 1951. Ecological animal geography. New York, McGraw-Hill.

Allen, E. T., and A. L. Day. 1935. Hot springs of the Yellowstone National Park. Carnegie Institution of Washington .

Allen, K. R. 1951. The Horokiwi stream. New Zealand Department Fisheries Bulletin No. 10.

Armitage, K. B. 1954. The comparative ecology of the riffle insect fauna of the Firehole River, Yellowstone National Park, Wyoming. Ph.D. Thesis, University of Wisconsin.

Bauer, C. M. 1948. Yellowstone-its underworld. Albuquerque, University of New Mexico Press.

Behney, W. H. 1937. Food organisms of some New Hampshire trout streams. Biological Survey of the Androscoggin, Saco, and Coastal Watersheds; Survey Report No. 2. New Hampshire Fish and Game Department, Concord. pp. 76-80.

Behning, A. L. 1929. Bericht über die Tätigkeit der Biologischen Wolga-Station im Jahre 1927. Arbeiten der Biologishen Wolga-Station Band IX, No. 4-5.

Berg, Kaj. 1948. Biological studies on the River Susaa. Folia Limnologica Scandinavica, No. 4.

Borecky, Gloria W. 1956. Population density of the limnetic Cladocera of Pymatuning Reservoir. Ecology $37:$ 719-727.

Ekman, S. 1911. Neue Apparate zur qualitativen und quantitativen Erfoshung der Bodenfauna der Seen. Int. Rev. Hydrobiol. 7: 146-204.

Frison, T. H. 1935. The Stoneflies, or Plecoptera, of Illinois. Bull. Ill. Nat. Hist. Survey 20: 281-371.

Frost, Winifred E. 1945. Discussion on the results obtained from investigations on the food and growth of brown trout (Salmo trutta. L.) in alkaline and acid waters. Proceedings of the Royal Irish Academy Vol. L. Sect. B, No. 19.

Gaufin, A. R. 1949. A comparative study of the bottomfauna productivity of the north and south forks of the Provo River at Stewart's Ranch, Utah. Abstract of paper given at the 11th Midwest Wildlife Conference.

Hague, A. 1887. Geological history of the Yellowstone National Park. Transactions of the American Institute of Mining Engineers.

Hayne, D. W. and R. C. Ball. 1956. Benthic productivity as influenced by fish predation. Limnol. and Oceanogr. 1: 162-175. 
Hess, A. D. 1941. New limnological sampling equipment. Limnological Society of America. sp. pub. No. 6.

Ide, F. P. 1940. Quantitative determination of the insect fauna of rapid water. Publications of the Ontario Fisheries Research Lab. No. 47. U. of Toronto Press.

$\rightarrow$ Johnson, W. E. and A. D. Hasler. 1954. Rainbow trout production in dystrophic lakes. J. Wildlife Mgt. 18: 113-134.

Lack, D. 1954. The natural regulation of animal numbers. Oxford, Clarendon Press.

Leonard, J. W. 1939. Comments on the adequacy of accepted stream bottom sampling techniques. Trans. 4th N.A. Wildlife Conf. 288-295.

$\rightarrow$ Linduska, J. P. 1942. Bottom types as a factor influencing the local distribution of mayfly nymphs. Canadian Ent. 74: 26-30.

$\rightarrow$ Maciolek, J. A. and P. R. Needham. 1951. Ecological effects of winter conditions on trout and trout foods in Convict Creek, California, Trans. Am. Fish. Soc. 81: 202-217.

Macan, T. T. and E. B. Worthington. 1951. Life in lakes and rivers. London, Collins.

Muttkowski, R. A. 1929. The ecology of trout streams in Yellowstone National Park. Roosevelt Wildl. Ann. 2: 155-240.

Needham, J. G., J. R. Traver, and Y. Hsu. 1935. The biology of mayflies. Ithaca, Comstock.

Needham, P. R. 1928. Quantitative studies of the fish food supply in selected areas. A biological survey of the Oswego River system. N.Y. State Cons. Dept., Suppl. to 17 th Ann. Rept. 220-232.

- 1929. Quantitative studies of fish food supply of selected areas. A biological survey of the Erie Niagara system; Supp1. 18th Ann. Rept. N.Y. State Cons. Dept. 220-232.

$\rightarrow-$ 1934. Quantitative studies of stream bottom foods. Trans. Amer. Fiṣh. Soc. 64: 238-247.

-1938. Trout streams. Ithaca, Comstock.

and R. L. Usinger. 1956. Variability in macrofauna of a single riffle in Prosser Creek, California, as indicated by the Surber sampler. Hilgardia 24: 383-409.
Pate, V. S. L. 1932. Studies on fish food supply in selected. areas. A biological survey of the Oswegatchie and Black River systems. Suppl. 21st Ann. Rept. N.Y. State Cons. Dept. 133-149.

-1934. Studies on fish food supply in selected areas of the Raquette watershed. A biological survey of the Raquette watershad. Suppl. 23rd, Ann. Rept. N.Y. State Cons. Dept. 136-157.

Pearse, A. S. 1939. Animal ecology. New York, McGraw Hill.

Pennak, R. W. 1947. Keys to the aquatic insects of Colorado. U. of Colo. Studies 2: 353-383.

- 1953. Fresh water invertebrates of the United States. New York, Ronald Press.

- and E. D. Van Gerpen. 1947. Bottom fauna production and physical nature of the substrate in northern Colorado trout streams. Ecology 28: 42-48.

Percival, E. and Whitehead. 1929. A quantitative study of the fauna of some types of stream bed. J. Ecol. 17: 283-314.

Petersen, C. G. J. 1911. Valuation of the sea. I. Rept. Dan. Biol. Sta. 20: 1-76.

Ricker, W. E. 1934. An ecological classification of certain Ontario streams. Univ. Toronto Studies 37: $1-114$.

Ross, H. H. 1944. The caddisflies, or Trichoptera, of Illinois. Bull. I11. Nat. Hist. Surv. 23: 1-326.

Sprules, W. M. 1947. An ecological investigation of stream insects in Algonquin Park, Ont. Univ. Toronto Studies 56: 1-81.

Standard methods for the examination of water, sewage, and industrial wastes. 1955. N.Y., American Public Health Association, Inc.

Surber, E. W. 1936. Rainbow trout and bottom fauna production in one mile of stream. Trans. Amer. Fish. Soc. 66: 193-202.

Taft, A. C. and L. Shapovalov. 1935. A biological survey of streams and lakes in the Klamath and Shasta National Forests of California. U.S. Bureau of Fisheries (mimeographed).

Thienemann, A. 1950. Verbreitungsgeschichte der Süsswassertierwelt Europas. Die Binnengewasser 18.

\title{
DAILY MOVEMENTS OF DESERT PUPFISH, CYPRINODON MACULARIUS, IN SHORE POOLS OF THE SALTON SEA, CALIFORNIA
}

\author{
GEORgE W. Barlow \\ Department of Zoology, University of California, Los Angeles
}

\section{INTRODUCTION}

The desert pupfish, Cyprinodon macularius Baird and Girard, is a small teleost (usual length 20-30 mm) widely distributed in the Colorado River Basin. Its normal habitat is desert springs and drainages, but it has established itself in the Salton Sea and associated shore pools (Miller 1943).

I frequently visited the shore pools during 1954 and 1955 in order to gather data for another problem. Causal observations of the pupfish revealed that they moved into and out of the shallow areas with some degree of predictability. Because of this the distribution of the fish at different times of the day was observed more carefully. At the same time changes in the water temperature were recorded.

The objective of this paper is to describe the 